\title{
Cellular contamination during automatic and manual staining of cytological smears
}

\author{
W. T. BARR, D. E. B. POWELL, AND J. B. RAFFAN \\ From the Department of Pathology, the General Hospital, Bridgend, Glamorgan
}

SYNOPSIS Three routine cervical smears were contaminated with adenocarcinoma cells from a malignant serous effusion which was being processed simultaneously in an automatic staining machine. Further investigation showed that cells were transferred in up to $17 \%$ of cases. However, with manual staining, the figure could be as high as $30 \%$. The possibility of misleading cellular transfer should therefore always be considered. Serous fluids should not be processed with routine cervical smears.

Considerable attention is given to the time necessary for skilled cytological technicians to carry out a cytology screening programme. Less attention is paid to the time taken for processing smears, but clearly some method of batch or automatic staining is essential. A striking instance of malignant cell transfer during automatic staining prompted this investigation into the frequency with which cells may be transferred.

\section{Materials and Methods}

\section{INITIAL INCIDENT OF ACCIDENTAL CONTAMINATION}

A batch of routine cervical smears from a local health authority clinic was stained by Papanicolaou's method together with hospital cytology specimens in a 23-station Shandon-Elliott slide staining machine. Three cervical smears were found to contain adenocarcinoma cells. It was then observed that two smears of peritoneal fluid, which had been stained at the same time, contained numerous adenocarcinoma cells (Figs. $1-3)$.

The cervical smears had been stained in the bottom holder of the double-tier rack on the Received for publication 12 February 1970. staining machine. The peritoneal fluid smears had been processed in the top tier.

All reagents from the successive baths on the staining machine were centrifuged and the cellular constituents of the wet deposits examined.

MECHANISM OF CONTAMINATION

The possibility that cells could be detached from slides in the upper tier, and thereafter lie on the fluid surface until they were picked up by the bottom tier slides as they emerged from the bath, was tested by transfer experiments.

Slides smeared with glycerine/egg albumen were used as receptors. Routine cervical smears or peritoneal fluid known to contain numerous adenocarcinoma cells were used as sources. The receptors were placed in a variety of positions in relation to the source of possible transfer.

Similar procedures were used to assess the extent of cell transfer using manual staining methods.

\section{FIXATION}

All the routine cervical smears were fixed using the Ministry of Health carbowax fixative. The concentrated carbofix was diluted with industrial methylated spirit and dropped on to the horizontal slide. They were kept in the horizontal 
position in a slide holder before being conveyed to the laboratory.

The peritoneal fluid responsible for the initial

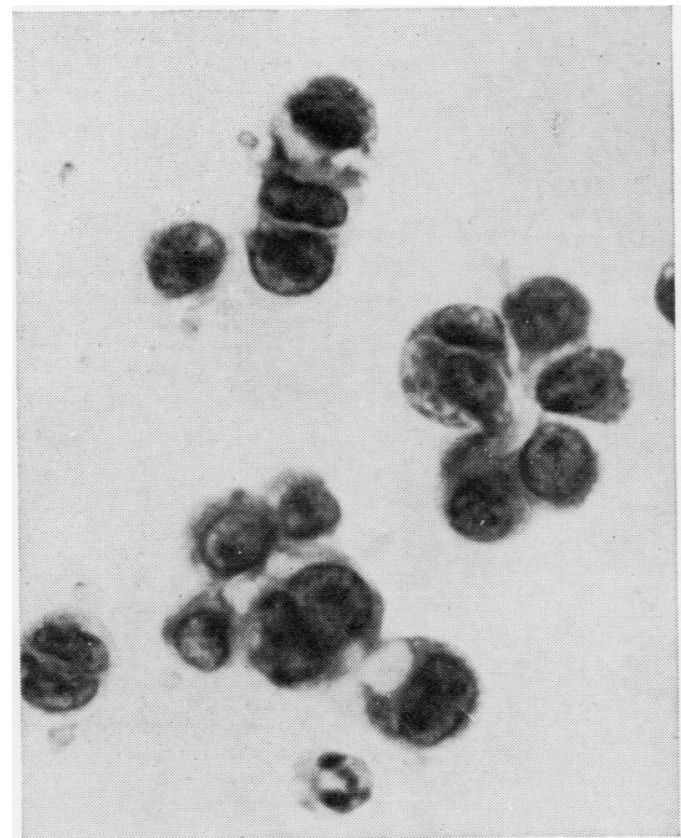

Fig. 1 Film of peritoneal fuid showing clumps of adenocarcinoma cells $\times 1,000$.

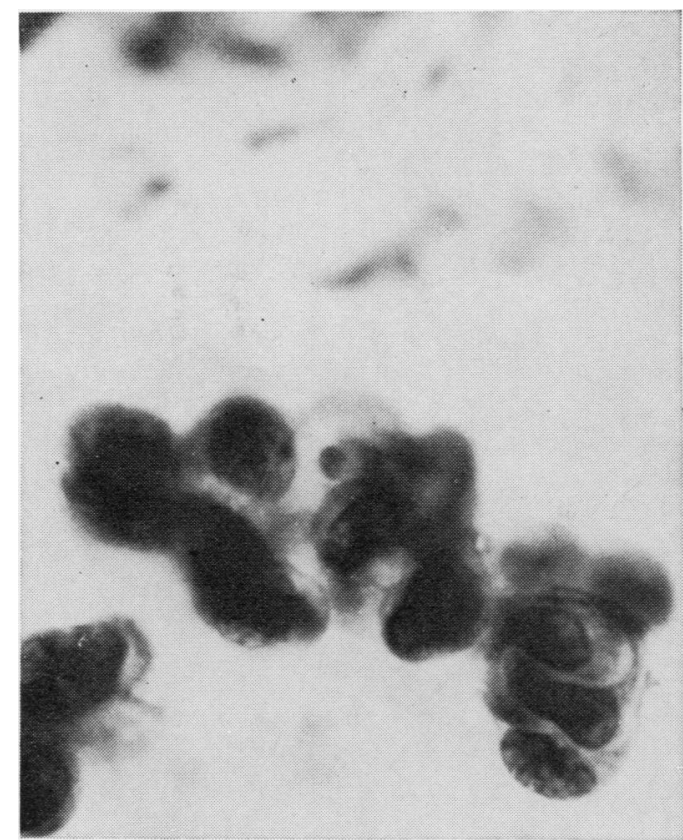

Fig. 2 Film of cervical smear showing clumps of adenocarcinoma cells in focus with background in different focal plane $\times 1,000$. incident of contamination had been wet-fixed with $95 \%$ alcohol for over half an hour. In the subsequent transfer experiments all smears and fluids were treated uniformly with carbofix.

\section{Results}

RECOVERY OF CELLS AFTER ACCIDENTAL CONTAMINATION

Water had been discarded from two of the baths, but the first 13 of the remaining 19 reagents contained carcinoma cells. The next five were free from contamination, but more cells were present in the last xylene bath. The cells were most numerous in the third (water), fourth (haematoxylin), and seventh (lithium carbonate). The fifth and sixth were the discarded water baths.

Not only were carcinoma cells found in the above instances, but also squamous cells were found in two, polymorphs in three, and a mixture of both in a further three.

\section{VERTICAL TRANSFER}

The test slide containing adenocarcinoma cells was placed as illustrated (Fig. 4) in relation to five albuminized slides in the bottom tier. Slides 2 and 3 picked up carcinoma cells during staining.

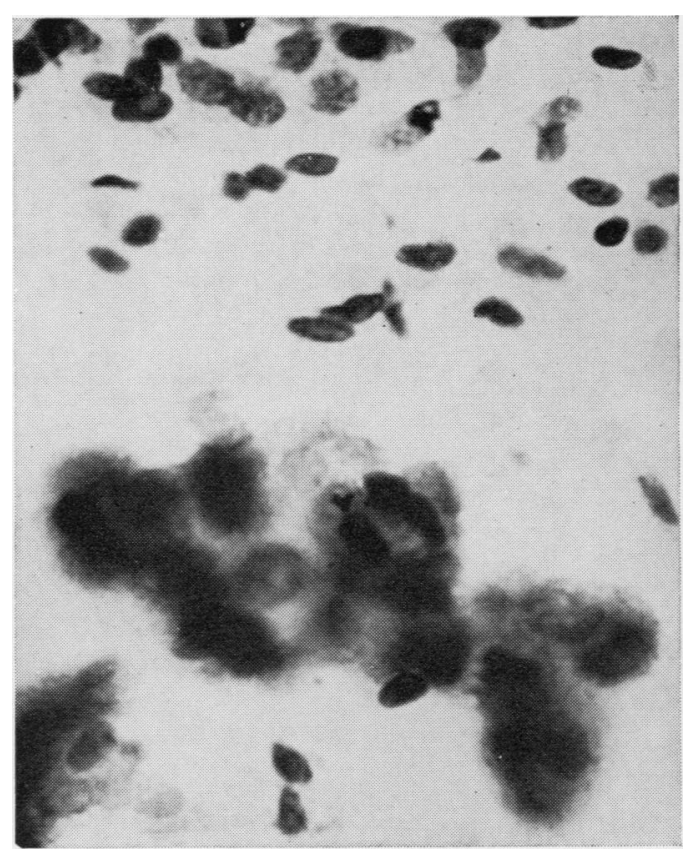

Fig. 3 Same field as in Fig. 2, showing cervical cells in focus with adenocarcinoma cells out of focus $\times 1,000$. 


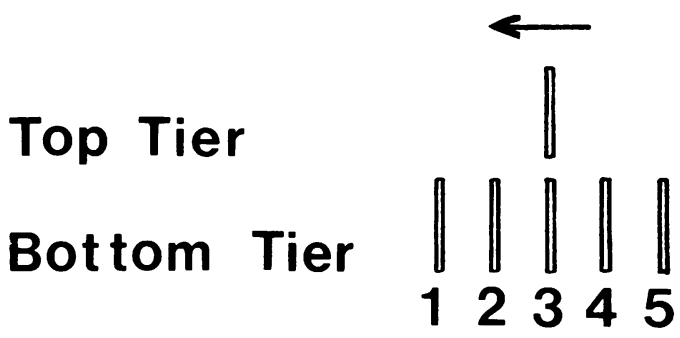

Fig. 4 Arrangement of slides to test for vertical transfer. The top tier slide contains adenocarcinoma cells. Slides 1-5 are albuminized.

INCIDENCE OF VERTICAL TRANSFER

DURING AUTOMATIC STAINING

Sixteen routine cervical smears were placed in the top tier, and 16 albuminized slides in the lower. Twelve such batches were stained, only four of which contained no contaminated slides. The results are shown in Table I.

Most of the cells found on the albuminized slides were intermediate and superficial squamesonly nucleated cells were counted. Fewer polymorphs were seen, and histiocytes were least common. Small tissue fragments of endocervical cells were sometimes found.

INCIDENCE OF HORIZONTAL CELL

TRANSFER DURING AUTOMATIC STAINING

Eight routine cervical smears were alternated with eight albuminized slides in the bottom holder. The top tier remained empty. Fifteen batches were stained, 10 of which contained contaminated slides (Table II).

Most of the cells found on the albuminized slides were superficial and intermediate squames, with a few polymorphs, histiocytes, endocervical cells, and one epithelial pearl.

\section{CELLULAR TRANSFER DURING BATCH MANUAL STAINING}

Twelve routine cervical smears were alternated with 12 albuminized slides on an ordinary manual staining rack. Seven batches were stained in this manner, all of which contained contaminated slides (Table III).

Most of the cells were squamous cells, with slightly fewer polymorphs, scanty red cells, and spermatozoa.

\section{DOUBLE TRANSFER EXPERIMENTS}

\section{DURING AUTOMATIC STAINING}

Eight slides of urinary deposit containing almost only epithelial cells were fixed wet with carbowax and alternated in the staining rack with eight peritoneal fluid smears. The latter were also

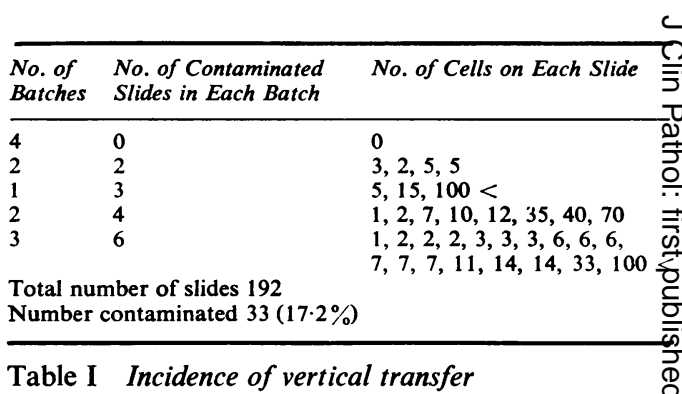

\begin{tabular}{lll}
\hline $\begin{array}{l}\text { No. of } \\
\text { Batches }\end{array}$ & $\begin{array}{l}\text { No. of Contaminated } \\
\text { Slides in Each Batch }\end{array}$ & No. of Cells on Each Slide \\
\hline 5 & 0 & 0 \\
6 & 1 & $1,2,10,10,30,40$ \\
2 & 2 & $1,5,17,20$ \\
1 & 4 & $2,7,9,17$ \\
1 & 5 & $1,3,5,10,26$ \\
Total number of slides 120 & \\
Number contaminated $19(15 \cdot 8 \%)$
\end{tabular}

Table II Incidence of horizontal cell transfer

\begin{tabular}{lll} 
& \\
\hline $\begin{array}{l}\text { No. of } \\
\text { Batches }\end{array}$ & $\begin{array}{l}\text { No. of Contaminated } \\
\text { Slides in Each Batch }\end{array}$ & No. of Cells on Each Slide \\
\hline 3 & 1 & $1,1,100<$ \\
2 & 5 & $1,1,1,4,4,5,5,16,31,43$, \\
1 & 6 & $3,4,7,9,29,99$ \\
1 & 8 & $1,1,1,3,30,30,50,200$ \\
Total number of slides 84 & \\
Number contaminated $27(32 \cdot 1 \%)$ & \\
\hline
\end{tabular}

Table III Cells transferred during manual staining

fixed wet with carbowax and contained numerous adenocarcinoma cells, but no epithelial cells.

One urine smear contained a clump of adeno $₹$ carcinoma cells. No such cells were found in the remaining seven smears. All eight peritoneat fluid smears contained epithelial cells. The num을 ber of cells on each slide varied from one to ninen

PICK-UP EXPERIMENT FROM USED STAINS N Albuminized slides were used to test the fre quency with which cells could adhere after the previous passage of cervical smears. The reagento baths were used unchanged for routine staining? over a 10-day period. The coated test slides wereo then processed first on the eleventh day. When? this was done on the machine three of 16 had? picked up cells, and five of 25 when processed manually. Subsequently, after 13 days' constant use the process was repeated immediately after staining a batch of cervical smears: four of 18 picked up cells on the machine and eight of 25 manually. 


\section{Discussion}

The processing of large numbers of routine cytological smears is greatly facilitated if an automatic staining machine is used. However, the incident of contamination described above, and the disturbing frequency of cell transfer in the automatic staining machine baths prompted us to abandon its use, that is, until manual batch staining methods were subjected to the same scrutiny, which showed that the incidence of transfer was appreciably higher. It is clearly impossible to process each slide individually, so that an automatic machine method is justifiable, if not essential, provided precautions are taken.

Several features help in the detection of cellular transfer. First, any 'unexpected' cells should alert the microscopist. Thus clear adenocarcinoma cells in routine cervical smears, especially when repeated in the same batch, should obviously be regarded as possible contaminants. Furthermore, these cells will appear alien to the general picture. Closer examination will show that transferred cells are not on the same focal plane as the main spread.

The need to prevent transfer of tissue, cells, or bacteria during processing of smears or sections has long been recognized. The methods to be adopted in cytology include care in keeping the stains and solutions free from sediment (Koss, 1968); daily cleansing and renewal of staining dishes (Cremer, 1968); thorough washing in running water; and filtration of solutions and a no-touch technique during mounting (Graham, 1963). However, even when all these precautions are taken cells may still be transferred with significant frequency.
The method of fixation is of considerable $\stackrel{\mathcal{C}}{=}$ importance. Unfortunately, one of the best $\vec{\partial}$ methods in the prevention of particulate transfer, namely, by heat, is only applicable in bacteriology $\underline{ }$ (Cremer, 1968). Neither rigid application of the recommended Ministry of Health carbowax method, nor prolonged exposure to $95 \%$ alcohol $\bar{C}$ prevent the possibility of contamination. Ruth 흘 Graham (1963) advocates coating all slides with $\frac{\bar{m}}{\sigma}$ celloidin, but this introduces difficulties in the $\mathbb{D}$ handling of large numbers. Furthermore, slides have to be stood in alcohol to remove the celloi- $)$ din. Graham also suggested that the likeliest. place of cell transfer was at the time of mounting. $\vec{\omega}$ This could not have been the explanation in our $\stackrel{\omega}{\circ}$ procedure because all mountants were applied $\overline{0}$ to the cover glass and not to the slide.

The hazard of contamination is greatest when malignant serous fluids are being processed. $\delta$ These should be stained only after cervical $\perp$ smears. Nevertheless, the most important of all 음 methods aimed at preventing contamination is the constant recognition of its possibility.

We are grateful to Miss G. Griffiths and Miss L. Barnes who undertook much of the screening.

References

Cremer, A. W. F. (1968). Automatic slide staining in clinical bacteriology. J. med. Lab. Technol., 25, 387-390.

Graham, R. M. (1963). The Cytologic Diagnosis of Cancer, 2nd ed., p. 347. Saunders, Philadelphia and London.

Koss, L. G. (1968). Diagnostic Cytology, 2nd ed., pp. 604 and 605. Pitman Medical, London. 